УДК 676.24

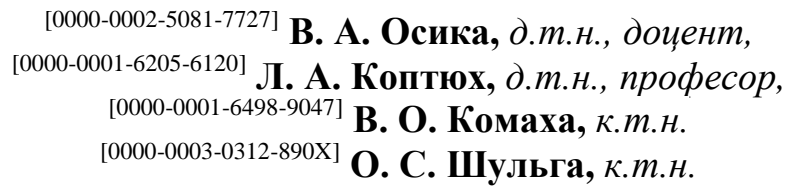

Київський національний торговельно-економічний університет вул. Кіото, 19, м. Київ, 02156, Україна

\title{
ФОРМУВАННЯ ЯКОСТІ ПАПЕРУ-ОСНОВИ ДЛЯ ВИГОТОВЛЕННЯ ВОДОЖИРОНЕПРОНИКНИХ ПАКУВАЛЬНИХ МАТЕРІАЛІВ
}

Стаття присвячена розробленню та реалізації концепиії формування якості паперуоснови для виготовлення вологоміџних водожиронепроникних паперових пакувальних матеріалів різного иільового призначення із заданим рівнем бар'єрних та захисних властивостей, яка полягає у створенні високощільної і зімкнутої структури пакувального паперу із заданим опором проникненню жиру та води. Проведено комплексні дослідження впливу виду иелюлози, ступеня помелу целюлозного волокна, складу і структури паперу-основи на вологоміцність, водонепроникність та жиронепроникність паперових пакувальних матеріалів. Встановлено, щцо найбільш ефективною волокнистою сировиною для виробництва паперу-основи для вологоміцних водожиронепроникних пакувальних матеріалів є сульфатна білена і небілена целюлоза із хвойних порід деревини за ступеня помелу 65-75

Ключові слова: папір-основа, ступінь помелу целюлози, щільність паперу, жиронепроникність, водонепроникність, паперові пакувальні матеріали.

Постановка проблеми. Для упакування жировмісної продукції застосовують паперові пакувальні матеріали, що відзначаються високим комплексом бар'єрних властивостей і захищають їі від контакту з киснем повітря. При цьому вони повинні бути мінімально проникні для ультрафіолетової частини спектра сонячного випромінювання.

Такі вимоги до пакувальних матеріалів пояснюються тим, що під час зберігання продукції з високим вмістом жирів спостерігається поступове зниження їхньої якості через перебіг біологічних і хімічних процесів. Крім цього, можуть мати місце процеси самоокиснення жирів, що призводить до деструкції зі складним ланцюгом реакцій, в результаті яких у складі продукту утворюються альдегіди, кетони, вільні жирні кислоти.

Таким чином забезпечення бар'єрних властивостей паперових пакувальних матеріалів, забезпечення їх непрозорості та жиронепроникності відіграють вирішальне значення в пакуванні жировмісних продуктів. Запропоновано досягнення високого рівня бар'єрних властивостей та механічної міцності за рахунок керованого регулювання структури паперу-основи та оброблення іiі поверхні речовинами, що забезпечують опір проникненню жиру та води. Пошук оптимальних матеріалів

(C) В. А. Осика, Л. А. Коптюх, В. О. Комаха, О. С. Шульга, 2019 DOI: 10.24025/2306-4412.3.2019.175305 для виготовлення паперу-основи водожиронепроникних матеріалів зумовлює необхідність вивчення паперотвірних властивостей найбільш поширених видів целюлози із різним ступенем розмелювання.

Аналіз останніх джерел досліджень і публікацій. Структура паперу являє собою набір хаотично орієнтованих у просторі целюлозних волокон, міцність та бар'єрні властивості якого забезпечуються тільки безпосередніми зв'язками волокон між собою [1-3]. Проведені дослідження показали, що для забезпечення низької водо- та повітропроникності паперу процес розмелювання целюлози слід проводити до досягнення глибокого ступеня розроблення волокна і незначного його укорочення $[4,5]$.

Водонепроникність можна підвищити шляхом збільшення щільності паперу [6-9]. Однак підвищення щільності та зниження загальної пористості не завжди супроводжуються зростанням показників водонепроникності, жиронепроникності та вологоміцності [10-14]. Папір-основа для виготовлення водожиронепроникних пакувальних матеріалів має відрізнятися підвищеними показниками непроникності, що може бути досягнуто, у першу чергу, шляхом високого ступеня розмелювання і фібрилювання волокна паперової 
маси, в результаті чого волокна створюють драглисту консистенцію, а також за рахунок додаткового ущільнення композиції паперового полотна.

Основа для паперового пакувального матеріалу повинна мати мікропористі властивості для забезпечення взаємодії із речовинами, що підвищують водожиронепроникність та інші бар'єрні властивості $[15,16]$. Крім того, розподіл пор повинен бути однорідним та рівномірним по всій товщі паперового полотна, що гарантує відповідні міцнісні властивості [17-19].

Існує ряд факторів, які сприяють підвищенню вологоміцності та водожиронепроникності паперу, а саме [3, 20]: якість паперової маси для виготовлення паперу, що, в свою чергу, оцінюється ступенем помелу целюлозного волокна та його розмірами, ступенем гідратації та фібрилювання під час розмелювання без надмірного укорочення; умови формування паперового полотна; властивості паперу-основи; реакційна здатність поверхні та наявність активних гідроксильних груп целюлозних волокон, що можуть вступати у взаємодію 3 компонентами складу для надання водонепроникності та вологоміцності.

Мета дослідження. Метою дослідження $\epsilon$ виявлення закономірностей та встановлення оптимальних параметрів виготовлення паперу-основи для водонепроникних та жиронепроникних паперових пакувальних матеріалів.

Матеріали і методи дослідження. В дослідженні використовували сульфатну небілену целюлозу хвойних порід деревини марки НС-2 виробництва АТ «Балтійська целюлоза» (Росія) та листяних порід деревини марки НС-3 виробництва АТ «Світлогорський целюлозно-картонний комбінат» (Білорусь).

Волокнисті напівфабрикати піддавали розпуску та розмелюванню до необхідного ступеня помелу (25-85ШР) в присутності води в лабораторному ролі VALLEY за швидкості барабана 500 об/хв. Ступінь помелу контролювали на приладі Шоппер-Ріглера за стандартною методикою [21]. Дослідні зразки паперу готували за допомогою листовиливного лабораторного приладу із комбінованою сушильною камерою Rapid Kothen.

Виклад основного матеріалу дослідження. 3 метою виявлення оптимального ступеня помелу різних видів целюлози та встановлення впливу зазначеного показника DOI: $10.24025 / 2306-44123.2019 .175305$

на властивості матеріалу були виконані дослідження зразків паперу із сульфатної листяної біленої, сульфітної хвойної біленої, сульфатної хвойної біленої і небіленої видів целюлози із ступенем помелу 15, 25, 45, 65, 75 і 85 ШР. Виготовлені зразки паперу досліджували за основними характеристиками, що забезпечують вимоги до пакування продукції з високим вмістом води та жиру.

Наведені залежності свідчать, що 3 підвищенням ступеня помелу целюлозного волокна в усіх зразках має місце зниження показника повітропроникності (рисунок 1).

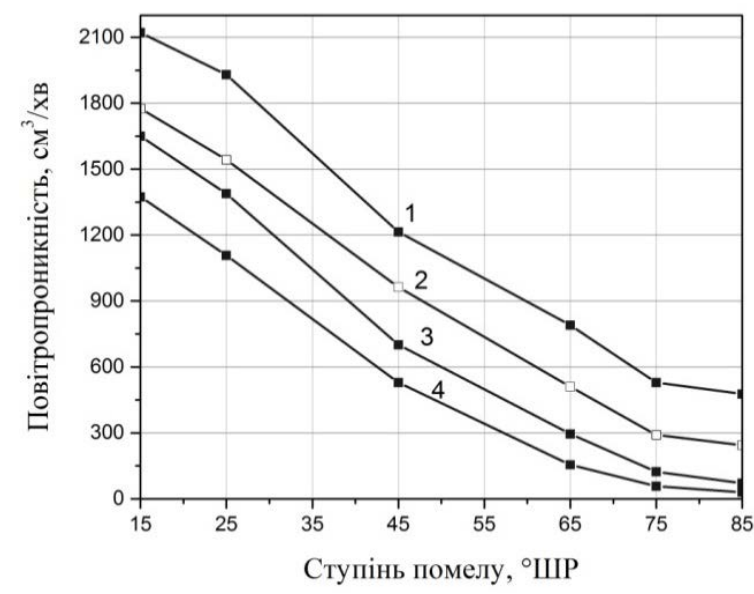

1 - сульфатна листяна білена; 2 - сульфітна хвойна білена; 3 - сульфатна хвойна білена; 4 - сульфатна хвойна небілена

\section{Рисунок 1 - Вплив ступеня помелу на повітропроникність паперу із різних видів целюлози}

Підвищений опір проникненню повітря забезпечується завдяки високій зімкнутості поверхні паперу, отриманої за рахунок застосування для його виготовлення високофібрильованої і гідратованої у процесі розмелювання волокнистої маси зі ступенем помелу 65-75 ШР.

Слід зазначити, що характер ступеневого зниження повітропроникності подібний як для листяної, так і для хвойної видів целюлози. Однак композиція паперу із листяної целюлози за усіх досліджуваних ступенів помелу має вищу проникність відносно повітря, при цьому абсолютні показники повітропроникності знижуються $32121 \mathrm{~cm}^{3} /$ хв для нерозмеленої целюлози (15ШР) до $477 \mathrm{~cm}^{3} / \mathrm{Xв}$ (ступінь помелу $-85^{\circ} Ш Р$ ).

Папір із хвойних видів целюлози відрізняється нижчою повітропроникністю порів- 
няно $з$ папером із листяної за усіх досліджуваних ступенів помелу.

За ступенем зменшення показника повітропроникності (за максимального ступеня помелу - 85ШР порівняно 3 нерозмеленим целюлозним волокном - $15^{\circ} \mathrm{ШP)} \mathrm{досліджувані}$ зразки паперу розташовуються в ряд: сульфатна листяна білена $(22,5 \%$ від вихідного) сульфітна хвойна білена (13\%) - сульфатна хвойна білена (4,3 \%) - сульфатна хвойна небілена $(2,11 \%)$.

Наведені дані свідчать про кращу здатність сульфатної біленої та небіленої целюлози i3 хвойних порід деревини до розмелювання та утворення менш полідисперсного волокна.

Висока якість паперової маси, ступінь розроблення і однорідність фібрильованих целюлозних волокон сприяють підвищенню щільності виготовленого з неї паперу (рисунок 2).

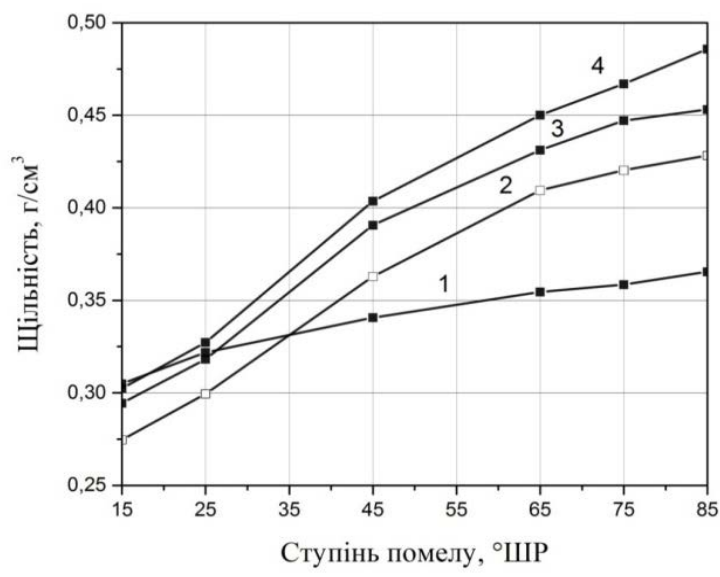

1 - сульфатна листяна білена; 2 - сульфітна хвойна білена; 3 - сульфатна хвойна білена; 4 - сульфатна хвойна небілена

Рисунок 2 - Вплив ступеня помелу на щільність паперу з різних видів целюлози

Однак слід зазначити, що практично за однакової щільності зразків паперу із нерозмеленої целюлози (15ШР) 3 підвищенням ступеня помелу волокна зростання значення показника щільності паперу із біленої та небіленої сульфатної целюлози хвойних порід деревини відбувається інтенсивніше i досягає більшого абсолютного значення - 0,45 та 0,48 г/см с $^{3}$ відповідно. Найменшим показником щільності за максимального ступеня помелу характеризується папір із сульфатної листяної біленої целюлози - 0,36 г/ $\mathrm{cm}^{3}$. Проміжне місце 3 показником щільності - 0,43 г/см ${ }^{3}$ при зазначеному ступені помелу займає папір із сульфітної хвойної біленої целюлози. Це пояснюється тим, що досліджувані волокна целюлози відрізняються своєю морфологічною будовою, розмірами за довжиною та шириною, міцністю, наявністю пор і капілярів та відношенням до розмелювання і фібрилювання.

Зі зростанням щільності паперу має місце підвищення основних показників його механічної міцності: руйнівного зусилля (рисунок 3) та опору продавлюванню (рисунок 4).

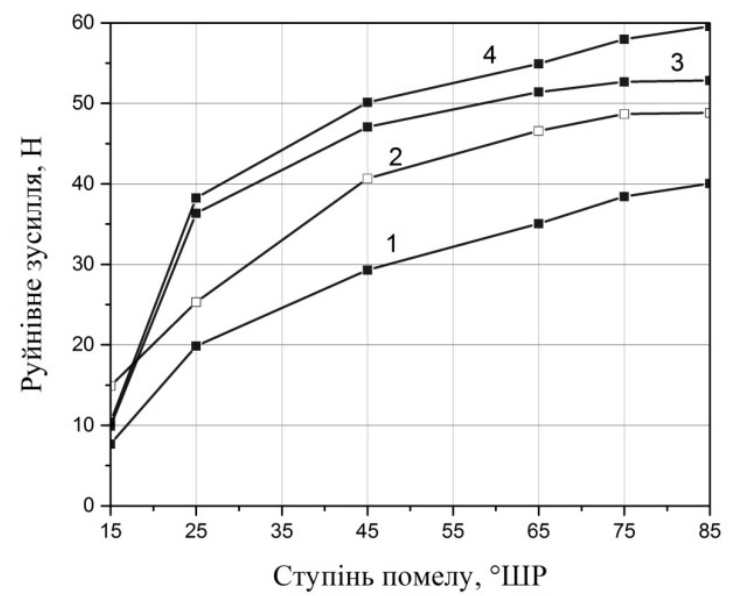

1 - сульфатна листяна білена; 2 - сульфітна хвойна білена; 3 - сульфатна хвойна білена; 4 - сульфатна хвойна небілена

Рисунок 3 - Вплив ступеня помелу на руйнівне зусилля паперу із різних видів целюлози

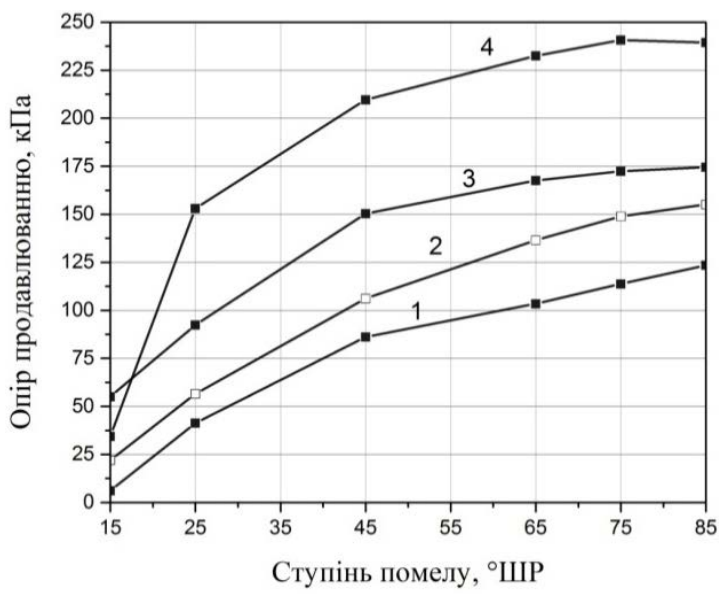

1 - сульфатна листяна білена; 2 - сульфітна хвойна білена; 3 - сульфатна хвойна білена; 4 - сульфатна хвойна небілена

\section{Рисунок 4 - Вплив ступеня помелу на опір продавлюванню паперу із різних видів целюлози}

Наведені залежності свідчать про те, що зі зростанням ступеня помелу целюлози - як біленої, так і небіленої - показники руйнівного зусилля та опору продавлюванню паперу зростають по затухаючій кривій 3 досягненням кращих результатів за ступеня помелу 
75-85ШР. Така зміна міцнісних властивостей паперу обумовлюється впливом основних факторів: розвиток міжволоконних сил зв'язків та укорочення целюлозних волокон у процесі розмелювання.

Це можна пояснити таким чином. Як відомо, міцність паперу складається 3 двох складових - міцності самих волокон і міцності міжволоконних зв'язків. Останній фактор прямо пов'язаний із площею контакту між волокнами під час формування паперу-основи. Саме завдяки збільшенню площі контакту між волокнами за підвищення ступеня помелу целюлози зростає міцність виготовленого з неї паперу.

На перших етапах розмелювання відбувається більш значне фібрилювання целюлозного волокна i, як наслідок, зростання міжволоконних сил зв'язку між ними, що сприяе підвищенню показників руйнівного зусилля $\mathrm{i}$ абсолютного опору продавлюванню паперу. Подальше підвищення ступеня помелу викликає укорочення волокон целюлози та їхне ослаблення в результаті механічної дії на них ножів розмелювального обладнання.

Такі зміни міцнісних властивостей відзначені для паперу, виготовленого із сульфатної біленої целюлози з хвойних порід деревини. Вищі значення досліджуваних показників має папір на основі небіленої сульфатної хвойної целюлози. Це можна пояснити вищим значенням ступеня полімеризації волокон небіленої целюлози, меншим їх руйнуванням порівняно з біленою целюлозою, підвищеним (до 8-10 \%) вмістом геміцелюлози, яка сприяє кращій гідратації волокон під час розмелювання, утворенню зв'язків між ними та збільшенню міцності міжволоконних зв'язків.

У процесі вибілювання сульфатної целюлози відбувається дегідратація целюлози та геміцелюлози, розрив молекулярного ланцюга 3 утворенням низькомолекулярних продуктів деструкції, які не видаляються під час промивання водою, і значне зниження в'язкості целюлози у міру видалення із неї лігніну.

Зазначені процеси позитивно впливають на здатність розробленої і фібрильованої маси целюлозних волокон формувати папір із підвищеним опором проходженню жиру (рисунок 5).

Встановлено, що вищий опір проникненню жиру має папір, який за рівних інших умов має вищу щільність. Так, зразки паперу, отримані із сульфатної біленої і небіленої целюлози, за ступеня помелу $75^{\circ}$ ШР після вили- вання мають щільність 0,45 і 0,48 г/с с $^{3}$ і характеризуються найнижчою жиропроникністю серед досліджуваних зразків - 453 і 311 отво$\mathrm{piв} / \mathrm{m}^{2}$ відповідно. Слід зазначити також, що повітропроникність, яка $\epsilon$ опосередкованим показником, що характеризує бар'єрні властивості паперу (газо-, водо-, жиронепроникність), зі зростанням щільності також знижується.

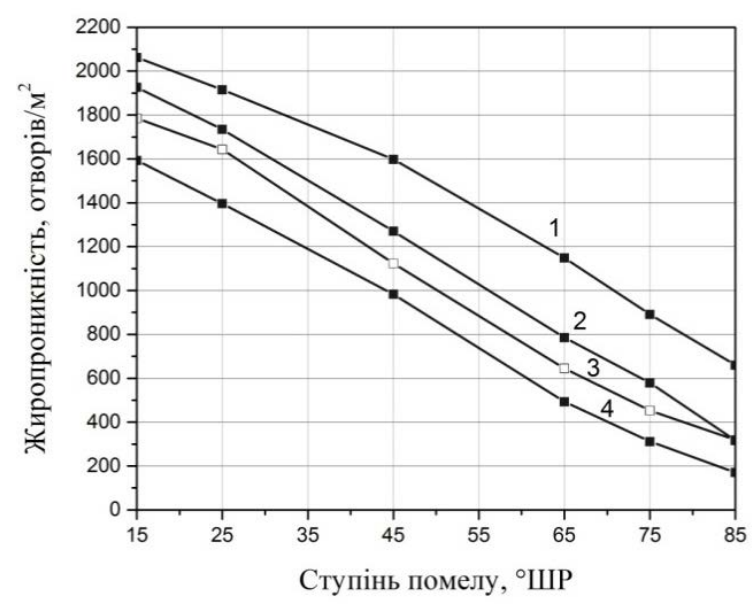

1 - сульфатна листяна білена; 2 - сульфітна хвойна білена; 3 - сульфатна хвойна білена; 4 - сульфатна хвойна небілена

Рисунок 5 - Вплив ступеня помелу на жиропроникність паперу із різних видів целюлози

Висновки 3 дослідження і перспективи подальшого розвитку у цьому напрямі. Наведені результати дають підставу констатувати, що найбільш придатними видами целюлози для виготовлення паперу-основи пакувального матеріалу з високим опором проникненню жиру є сульфатна білена та небілена целюлоза із хвойних порід деревини. Папір, отриманий із зазначених видів целюлози, характеризується кращими показниками механічних та бар'єрних властивостей порівняно 3 папером із сульфітної хвойної та сульфатної листяної видів целюлози за однакового ступеня помелу.

Наведені залежності свідчать про те, що 3 підвищенням ступеня помелу целюлозного волокна і щільності паперу знижуються показники його пористості. Однак розмелювання целюлозного волокна вище $75^{\circ}$ ШР не сприяє значному зростанню механічної міцності паперу. Це відбувається за рахунок зменшення міцності целюлозного волокна внаслідок розпушування структури та його укорочення. Крім того, процес такого помелу є довготривалим та більш енергозатратним. 


\section{Список літератури}

[1] П. С. Примаков, та В. А. Барабаш. Технологія паперу $i$ картону. Київ: ЕКМО, 2008.

[2] Д. М. Фляте, Бумагообразующие свойства волокнистых материалов. Москва: Лесная промышленность, 1990.

[3] В. А. Осика, та Л. А. Коптюх, Паперові пакувальні матеріали: монографія. Київ: КНTEУ, 2018.

[4] А. В. Вураско, и Е. И. Фролова, "Влияние степени помола на сорбционные свойства целлюлозы из недревесного растительного сырья", Леса России и хозяйство в них, c. 123-126, 2013.

[5] Л. А. Коптюх, "Разработка и организация производства жиронепроницаемой и влагопрочной упаковочной бумаги", Целлюлоза. Бумага. Картон, № 11-12, с. 28-30, 1997.

[6] И. И. Карпунин, В. В. Кузьмич, и Т. Ф. Балабанова, "Технологические режимы переработки растительного сырья для производства упаковки", Наука $u$ техника, № 3, с. 34-38, 2011.

[7] А. В. Кулешов, и А. С. Смолин, "Бумагообразующие свойства вторичных растительных волокон", Химия растительного сырья, № 2, с. 110-112, 2008.

[8] М. В. Мирзаева, и Х. А. Бабаханова, "Факторы, влияющие на специфические свойства бумаги конкретного назначения", Известия выстих учебных заведений. Проблемь полиграфии и издательского дела, № 2, с. 13-17, 2013.

[9] О. А. Мишурина и др. "Анализ влияния качества целлюлозного сырья на прочностные и сорбционные свойства упаковочных видов картона", Международный журнал прикладных и фундаментальных исследований, № 1, с. 9-13, 2017.

[10] H. T. Sahin, and M. B. Arslan, "A study on physical and chemical properties of cellulose paper immerse din various solvent mixtures", International Journal of Molecular Sciences, vol. 9, iss. 1, pp. 78-88, 2008.

[11] D. Akuzova, F. Brummer, and T. Vladkova, "Some possibilities to reduce the biofilm formation on transparent siloxane coatings", Colloids and Surfaces B-Biointerfaces, vol. 104, pp. 303-310, 2013.

[12] V. V. Gorazdova, E. V. Dernova, D. A. Dul'kin, and E. O. Okulova, "The effect of fiber

(c) В. А. Осика, Л. А. Коптюх, В. О. Комаха, О. С. Шульга, 2019 DOI: $10.24025 / 2306-4412.3 .2019 .175305$ brushing and shortening when beating on the strength, deformation and fracture toughness properties of cellulosic materials", Lesnoy Zhurnal-Forestry Journal, no. 2, pp. 109121, 2018.

[13] W. W. Sampson, "Materials properties of paper as influenced by its fibrous architecture", International Materials Reviews, vol. 54, no. 3, pp. 134-156, 2009.

[14] T. Hosoya, H. Kawamoto, and S. Saka, "Cellulose-hemicellulose and celluloselignin interaction sin wood pyrolysis at gasification temperature", Journal of analytical and applied pyrolysis, vol. 80, no. 1, p. 118125, 2007.

[15] M. Vaha-Nissi, T. Lappalainen, and K. Salminen, "The wet strength of waterand foam-laid cellulose sheets prepared with polyamideamine-epichlorohydrin (PAE) resin", Nordic Pulp \& Paper Research Journal, vol. 33, no. 3, pp. 496-502, 2018.

[16] D. Yang, T. C. Stimpson, J. Soucy, A. Esser, and R. H. Pelton, "Increasing wet adhesion between cellulose surfaces with polyvinylamine", Cellulose, vol. 26, no. 1, pp. 341353, 2019.

[17] Э. Р. Муллина, и др. "Исследование влияния химического состава целлюлозы на физико-механические свойства бумаги", Современные наукоемкие технологии, № 9, с. 32-38, 2015.

[18] S. Iwamoto, K. Abe, and H. Yano, "The effect of hemicellulose son wood pulp nanofibrillation and nanofiber network characteristics", Biomacromolecules, vol. 9, no. 3, pp. 1022-1026, 2008.

[19] H. Yang, et al., "Characteristics of hemicellulose, cellulose and ligninpyrolysis", Fuel, vol. 86, no. 12-13, pp. 1781-1788, 2007.

[20] В. Осика, Л. Коптюх, В. Комаха, О. Шульга, та К. Мостика, "Паперотвірні властивості целюлози різних видів та ступенів помелу", Технічні науки та технологіï, № 1 (15), с. 227-234, 2019.

[21] Целюлоза. Готування лабораторних листів для фізичних випробувань. Ч. 2. Метод із застосуванням апарату PanidКеттена (ISO 5269-2:2004,IDT):

ДСТУ ISO 5269-2:2015. [Чинний від 2016-01-01]. Київ: Держспоживстандарт України, 2015. (Національний стандарт України). 


\section{References}

[1] P. S. Prymakov, and V. F. Barabash, Technology of paper and cardboard. Kyiv: EKMO, 2008 [in Ukrainian].

[2] D. M. Fliate, Paper-forming properties of fibrous materials. Moscow: Lesnaia promyshlennost, 1990 [in Russian].

[3] V. A. Osyka, and L. A. Koptiukh, Paper packaging materials. Kyiv: KNUTE, 2018 [in Ukrainian].

[4] A. V. Vurasko, and E. Y. Frolova, "The influence of the degree of grinding on the sorption properties of cellulose from nonwood plant materials", Lesa Rossii $i$ khoziaistvo v nikh, vol. 1, pp. 123-126, 2013 [in Russian].

[5] L. A. Koptiukh, "Development and organization of production of greaseproof and moisture-proof packaging paper", Tcelliuloza. Bumaga. Karton, vol. 11-12, pp. 28-30 1997 [in Russian].

[6] I. I. Karpunin, V. V. Kuzmych, and T. F. Balabanova,"Technological modes of processing vegetable raw materials for the production of packaging", Nauka i tekhnika, vol. 3, pp. 34-38, 2011 [in Russian].

[7] A. V. Kuleshov, and A. S. Smolyn, "Paperforming properties of secondary plant fibers", Khimiia rastitelnogo syria, vol. 2, pp. 110-112, 2008 [in Russian].

[8] M. V. Mirzaeva, and Kh. A. Babakhanova, "Factors affecting the specific properties of a paper of a specific purpose", Izvestiia vysshikh uchebnykh zavedenii. Problemy poligrafii i izdatelskogo dela, vol. 2, pp. 1317, 2013 [in Russian].

[9] O. A. Mishurina, etal., "Analysis of the influence of the quality of cellulosic raw materials on the strength and sorption properties of packaging types of cardboard", Mezhdunarodnyi zhurnal prikladnykh i fundamentalnykh issledovanii, vol. 1, pp. 9-13, 2017 [in Russian].

[10] H. T. Sahin, and M. B. Arslan, "A study on physical and chemical properties of cellulose paper immerse dinvarious solvent mixtures", International Journal of Molecular Sciences, vol. 9 (1), pp. 78-88, 2008.

[11] D. Akuzova, F. Brummer, and T. Vladkova, "Some possibilities to reduce the biofilm formation on transparent siloxane coatings", Colloids and Surfaces B-Biointerfaces, vol. 104. pp. 303-310, 2013.
[12] V. V. Gorazdova, E. V. Dernova, D. A. Dul'kin, and E. O. Okulova, "The effect of fiber brushing and shortening when beating on the strength, deformation and fracture toughness properties of cellulosic materials", Lesnoy Zhurnal-Forestry Journal, vol. 2, pp. 109121, 2018.

[13] W. W. Sampson, "Materials properties of paper as influenced by its fibrous architecture", International Materials Reviews, vol. 54 (3), pp. 134-156, 2009.

[14] T. Hosoya, H. Kawamoto, and S. Saka, "Cellulose-hemicellulose and celluloselignin interaction sin wood pyrolysis at gasification temperature", Journal of analytical and applied pyrolysis, vol. 1 (80), pp. 118125, 2007.

[15] M. Vaha-Nissi, T. Lappalainen, and K. Salminen, "The wet strength of waterand foam-laid cellulose sheets prepared with polyamideamine-epichlorohydrin (PAE) resin", Nordic Pulp \& Paper Research Journal, vol. 33, no 3, pp. 496-502, 2018.

[16] D. Yang, T. C. Stimpson, J. Soucy, A. Esser, and R. H. Pelton, "Increasing wet adhesion between cellulose surfaces with polyvinylamine", Cellulose, vol. 26, no. 1, pp. 341-353, 2019.

[17] E. R. Mullina, et al., "Study of the influence of chemical composition of cellulose on physical and mechanical properties of paper", Sovremennye naukoemkie tekhnologii, vol. 9, pp. 32-38, 2015 [in Russian].

[18] S. Iwamoto, K. Abe, and H. Yano, "The effect of hemicellulose son wood pulp nanofibrillation and nanofiber network characteristics", Biomacromolecules, vol. 9, no. 3, pp. 1022-1026, 2008.

[19] H. Yang, et al., "Characteristics of hemicellulose, cellulose and ligninpyrolysis", Fuel, vol. 86, no. 12-13, pp. 1781-1788, 2007.

[20] V. Osyka, L. Koptiukh, V. Komakha, O. Shulha, and K. Mostyka, "Paper-forming properties of cellulose of different types and degrees of grinding", Tekhnichni nauky ta tekhnolohii, vol. 1 (15), pp. 227-234, 2019 [in Ukrainian].

[21] Cellulose. Preparing of laboratory lists for physical tests. Part 2. Metod with the use of Rapid-Ketten apparatus (ISO 5269-2:2004, IDT): DSTU ISO 5269-2:2015. [Effective from 2016-01-01]. Kyiv: Derzhspozhyvstandart Ukrainy, 2015. (Natsionalnyi standart Ukrainy). 
V. A. Osyka, D. Tech. Sc., associate professor,

L. A. Koptiukh, D. Tech. Sc., professor,

V. O. Komakha, $P$. $D$.,

e-mail:v.komakha@knteu.kiev.ua

O. S. Shulga, $P h$. D.

Kyiv National University of Trade and Economics, Kioto str., 19, Kyiv, 02156, Ukraine

\section{BASE PAPER QUALITY FORMATION FOR MANUFACTURE OF WATER-RESISTANT PACKAGING MATERIALS}

Introduction. The article is devoted to the development and implementation of the concept of paper base quality formation for the manufacture of moistureproof grease- and waterproof paper packaging materials for various purposes with a controlled level of barrier and protective properties, which consists in the creation of high-density and closed structure of packaging paper with the given grease and water resistance. Comprehensive studies of the influence of cellulose type, the degree of grinding of cellulose fiber, the composition and structure of the base paper on the moisture, water and grease resistance of paper packaging materials. It is established that sulfate bleached and unbleached pulp from coniferous wood at a grinding rate of $65-75^{\circ} \mathrm{SR}$ is the most effective fibrous raw material for the production of base paper for moisture-proof water-proof packaging materials.

The aim of the work. The purpose of the study is to identify patterns and establish optimal parameters for the manufacture of base paper for waterproof and greaseproof paper packaging materials.

Research methods. In the study sulfate unbleached cellulose of coniferous wood of the NS-2 brand of production of JSC Baltic Cellulose (Russia) and hardwood of the brand of NS-3 production of JSC Svetlogorsk Pulp and Cardboard Mill (Belarus) were used. Fibrous semi-finished products were subjected to dissolution and milling to the required degree of grinding $\left(25-85^{\circ} \mathrm{C}\right)$ in the presence of water in the laboratory role of VALLEY at a drum speed of $500 \mathrm{rpm}$. The degree of grinding was monitored on a Shopper-Riegler apparatus according to the standard method [30]. The paper samples were prepared using a sheet-fed laboratory instrument with a Rapid Kothen Combined Dryer.

Problem formulation. To pack fatty products, paper packaging materials are used that have high barrier properties and protect it from contact with oxygen. It is proposed to achieve a high level of barrier properties and mechanical strength due to controlled regulation of base paper structure and treatment of its surface with substances that provide grease and water resistance.

Description of the main material of the article. Paper samples were examined for basic characteristics that meet the requirements for packaging products with high water and grease content. The increased air resistance is ensured due to high closure of the paper surface obtained by using for its manufacture of highly fibrillated and hydrated in the process of grinding fibrous mass with a degree of grinding $65-75^{\circ} \mathrm{SR}$.

High quality pulp, the degree of development and homogeneity of fibrillated cellulose fibers increase the density of produced paper. Higher degree of fiber milling given more good value of the density of paper from bleached and unbleached sulfate cellulose of coniferous wood is more intense and reaches a greater absolute value -0.45 and $0.48 \mathrm{~g} / \mathrm{cm}^{3}$, respectively. With the increase of paper density, there is an increase in the main indicators of its mechanical strength: destructive force and resistance to stranding.

Paper samples obtained from sulfur bleached and unbleached pulp at a grinding rate of $75^{\circ} S R$ after pouring have a density of 0.45 and $0.48 \mathrm{~g} / \mathrm{cm}^{3}$ and are characterized by the lowest grease permeability among the tested samples - 453 and 311 holes $/ \mathrm{m}^{2}$, respectively.

Conclusions and recommendations. It is established that sulfate bleached and unbleached pulp from coniferous wood at a grinding rate of $65-75^{\circ} \mathrm{SR}$ is the most effective fibrous raw material for the production of base paper for moistureproof grease and waterproof packaging materials.

Keywords: base paper, cellulose grinding degree, paper density, greaseproofness, waterproofness, paper packaging materials.

Стаття надійшла 07.08.2019

Прийнято 06.09.2019

(C) В. А. Осика, Л. А. Коптюх, В. О. Комаха, О. С. Шульга, 2019 DOI: $10.24025 / 2306-4412.3 .2019 .175305$ 